\title{
Coronavirus (COVID-19) in Haiti: A Call for Action
}

\author{
James Louis-Jean ${ }^{1}$ (1) $\cdot$ Kenney Cenat ${ }^{2} \cdot$ Debbie Sanon $^{3} \cdot$ Ruthonce Stvil $^{4}$
}

Published online: 17 April 2020

(c) Springer Science+Business Media, LLC, part of Springer Nature 2020

\begin{abstract}
Recently, the cholera outbreak in Haiti demonstrated just how unprepared the country is to rapidly isolate an outbreak of this magnitude, and its vulnerability to the COVID-19 pandemic. This communication briefly examines the health system in Haiti and its vulnerability toward the COVID-19 outbreak.
\end{abstract}

Keywords Global health · Pandemic · Coronavirus · Haiti

\section{Introduction}

The coronavirus (COVID-19) pandemic is a major, worldwide public health challenge that originated in Wuhan, China in December 2019. While health officials in China were unable to contain COVID-19 within their country over the course of a few months, it was rapidly transmitted based on human to human contact to more than 105 countries and territories [1]. This is concerning for countries with weak public health systems (such as Haiti and others) and the spread of the virus within these countries is a major concern expressed by the World Health Organization (WHO). Recently, the cholera outbreak in Haiti demonstrated just how unprepared the country is to rapidly deal with an outbreak of this magnitude, and its vulnerability to the COVID-19 outbreak. This communication briefly examines the health system in Haiti and its vulnerability toward the COVID-19 outbreak.

James Louis-Jean

louisjea@unlv.nevada.edu

1 University of Nevada Las Vegas, Las Vegas, NV, USA

2 Department Chair, Homestead Middle School, Homestead, FL, USA

3 Florida State University, Tallahassee, FL, USA

4 Florida Agricultural and Mechanical University, Tallahassee, FL, USA

\section{Coronavirus in Haiti}

In response to the spread of COVID-19, the Haitian government, with the help of WHO and the U.S. Centers for Disease Control and Prevention (CDC), took proactive steps and quickly prepared health professionals to monitor and detect infected travelers at the two international airports. Additionally, Haitian authorities also shut down the border with the Dominican Republic. These efforts were undertaken to prevent the rapid spread of COVID-19 in Haiti by minimizing movement to and from the country and by identifying any possibly infected persons before entry. But, how really prepared is Haiti to deal with another outbreak of a highly contagious disease?

The population in Haiti is about 11 million with $35 \%$ of the people residing in the capital, Port-au-Prince [2]. The health care system is problematic. Only 900 health institutions are available to the 11 million inhabitants, among which $38 \%$ are public institutions, $42 \%$ private, and $20 \%$ mixed. Nearly half of these institutions are located in the capital [2, 3]. On average, the public health care spending in Haiti is 13 U.S. Dollars per capita a year, which is below the average (15 U.S. Dollars) for low-income countries. By comparison, neighboring countries such as Dominican Republic and Cuba-with the same population as Haiti, respectively spend 180 and 781 U.S. Dollars per capita a year [4]. Over the years, the Haitian government has systematically reduced its national health budget from 16.6 to $4.4 \%$ since 2004. Surprisingly, the Haitian Parliament continue to receive more funding than its Ministry of Public Health and Population (Ministère de la Santé Public et de la Population, MSPP). For the 2017-2018 national budget, the 
Parliament received 7.2 billion Haitian gourdes (7.2 million U.S. Dollars) compared to the 6.1 billion Haitian gourdes (6.1 million U.S. Dollars) allocated to MSPP [5]. The MSPP reported that $64 \%$ of Haiti's health budget is provided by international assistance through many Non-Government Organizations (NGOs).

With limited medical supplies, infrastructures, and health professionals, Haiti is currently very vulnerable against the COVID-19 virus. The highly pathogenic Coronavirus is highly transmittable, causes fatal pneumonia, and infects lower respiratory airways, resulting in pulmonary failure and death. The virus is transmitted from human to human by contact from respiratory droplets, coughing, and sneezing. As a result, it can live on various surfaces for a relatively long period of time. COVID-19 has an incubation period of 5-14 days. Infected individuals and asymptomatic individuals are the primary sources of transmission. At the time of this writing, the virus has already produced a mortality rate of about 5.6\% and affected large numbers of people, causing many deaths [1].

While the virus has spread in a number of countries in the American continent, Haiti is one the latest countries to have had confirmed cases of the virus. On 19 March 2020, Haitian authorities reported the first two cases of the deadly COVID-19 disease in Haiti [6]. Based on previous experiences, including the 7.0 magnitude earthquake in 2010 and the cholera outbreak, the public health system in Haiti is not equipped to battle a pandemic of this magnitude. An immediate plan of action is urgently needed. While the public hospitals in Haiti receive a large volume of patients daily, they are operating with low funding and inadequate medical equipment. They are currently in an unstable position and are not ready to diagnose individuals with COVID-19 as they do not have the available testing to determine if an individual is infected with the virus. To date, of the 11 million inhabitants, only 218 people have been tested for COVID-19 with 20 confirmed positive cases and one reported death. The limited number of tests is a great disadvantage when compared to the neighboring country, Dominican Republic where more than 4000 tests were conducted with 1488 positive cases and 68 reported deaths [1]. Analyses showed failures to rapidly test individuals for the COVID-19 pandemic resulted in major catastrophe. This is the case of the Unites States of America (USA) which had a slow response to the pandemic.

\section{Public Reaction and Engagement}

The lack of information and understanding about the virus in Haiti is another obstacle. Many believe that the virus is the result of sin and it is God's punishment on humans for their sinful ways. Others believe that the world's elite manufactured the virus in order to kill minorities and annihilate those in poor countries. A selected number of Haitians have the accurate information about the deadly disease and understand that the virus can infect anyone regardless of religious background or ethnicity. As they understand the risks and preventative measures to combat the virus, the majority of the population still does not have the necessary tools and equipment to respond. The challenge is due to the fact that only $36 \%$ of the population has access to electricity, nearly $56 \%$ has access to clean water, and $28 \%$ has access to basic sanitation [7, 8]. Altogether, the Haitian government and public health officials need to continuously engage in circulating information, providing guidance, and clarifying misinformation to the public. This nationwide campaign can be facilitated through press briefings, announcements on radio and television stations, and through text messages using WhatsApp-which is a well-established form of conversation among Haitians living in Haiti and abroad. In doing so, this campaign will consequently help reduce the risk of transmission and infection in Haiti.

Acknowledgements Thanks are due to Magdonald Aimé for his contribution and to the reviewers for their constructive criticisms.

Funding This research did not receive any specific grant from public, commercial, government, commercial or non-profit funding agencies.

Data Availability All materials and data used in this communication are publicly available and are cited throughout the text.

\section{Compliance with Ethical Standards}

Conflict of Interest There are no conflicts to declare.

Ethical Approval and Consent Ethical approval or consent was not applicable for this paper.

\section{References}

1. Coronavirus Disease 2019 (COVID-19) Situation Report-77. (2020). World Health Organization. Retrieved from https://www. who.int/docs/default-source/coronaviruse/situation-reports/20200 406-sitrep-77-covid-19.pdf?sfvrsn=21d1e632_2.

2. Population Division World Population Prospects 2019. (2019). United Nations Department of Economic and Social Affairs, Population Division. Retrieved from https://population.un.org/wpp/.

3. Institut Haïtien de l'Enfance (Haiti); ICF International. Évaluation de Prestation des Services de Soins de Santé, Haïti, 2013. (2014). Rockville, Maryland, USA: IHE et ICF International. Retrieved from https://mspp.gouv.ht/site/downloads/EPSSS.pdf.

4. Haiti: New World Bank Report Calls for Increased Health Budget and Better Spending to Save Lives. (2017). The World Bank. Retrieved from https://www.worldbank.org/en/news/press-relea se/2017/06/26/haiti-new-world-bank-report-calls-for-increasedhealth-budget-and-better-spending-to-save-lives.

5. Saint-Pré, P. (2020). En Réduisant Chaque Année le Budget de la Santé, les Autorités ont Entretenu l'Impréparation d'Haïti à Faire 
Face au Coronavirus. Le Nouvelliste. Retrieved from https://lenou velliste.com/article/214079/en-reduisant-chaque-annee-le-budge t-de-la-sante-les-autorites-ont-entretenu-limpreparation-dhaiti-afaire-face-au-coronavirus.

6. Coronavirus Disease 2019 (COVID-19) Situation Report-61. (2020). World Health Organization. Retrieved from https://www. who.int/docs/default-source/coronaviruse/situation-reports/20200 321-sitrep-61-covid-19.pdf?sfvrsn=6aa18912_2.

7. Herrer, J., Lamaute-Brisson, N., Milbin, D., Roubaud, F., SaintMacary, C., Torelli, C., et al. (2014). L'évolution des Conditions de Vie en Haïti Entre 2007 et 2012. La réplique sociale du séisme.
Paris, Port-au-Prince. Retrieved from www.ihsi.ht/pdf/ecvmas/ analyse/IHSI_DIAL_Rapport_complet_11072014.pdf.

8. Country Program Evaluation: Haiti 2011-2015. Washington, DC: Inter-American Development Bank. Retrieved from https://publi cations.iadb.org/en/country-program-evaluation-haiti-2011-2015.

Publisher's Note Springer Nature remains neutral with regard to jurisdictional claims in published maps and institutional affiliations. 